\title{
Integrasi Statistical Process Control dan Failure Mode And Effect Analysis Guna Meminimalisasi Defect Pada Proses Produksi Pipa PVC
}

\author{
${ }^{(1)}{ }^{*}$ Ananda Hermawan, ${ }^{(2) * N i n a ~ A i n i ~ M a h b u b a h ~}$ \\ ${ }^{(12)}$ Program Studi Teknik Industri, Fakultas Teknik, Universitas Muhammadiyah Gresik, \\ Jl. Sumatera No.101 GKB, Gresik - Indonesia 61121 \\ *Email:n.mahbubah@umg.ac.id, anandahrmwnn@gmail.com
}

Diterima: 30.09.2021 Disetujui: 14.10.2021 Diterbitkan: 24.10.2021

\begin{abstract}
Quality can be referred as fitness to use. Furthermore, Quality standard is considered as a way in order to meet customers' need. PT AZ is a manufacture enterprise which produce polyvinyl chloride (PVC) pipes. This firm has been implementing a Standard Operating Procedure (SOP) in maintaining defect with no more than 2,5\% reject product during process production. However, such defects have been happened in production line which were not meet company standards. This study aims to evaluate defect along production process in order to find suitable solution in improving product quality. Seven Tools and Failure and Mode and Effect Analysis (FMEA) were used as research method. The results showed that there were 3 types of defects, namely spot defect, sink marks ant scratch defect. Furthermore, the results of the Cause-and-effect diagram show that human error, materials and machine are considered as main factors in contributing such defect. In addition, result from FMEA analysis detect that analysis and calculation of the highest RPN 147, namely the human factor is considered as the highest Risk Priority Number with 147 score. This study suggest that further training and supervision should be give to employees in order to improve employers" knowledge
\end{abstract}

Keywords: Quality, Defect, Seven Tools, FMEA, RPN, PVC

\begin{abstract}
ABSTRAK
Kualitas merupakan kesesuaian suatu produk berdasarkan sudut pandang pengguna produk. Standarisasi mutu merupakan upaya perusahaan dalam memenuhi kualitas sesuai kebutuhan konsumen. PT. AZ sebagai produsen berbagai jenis pipa PVC telah menerapkan standarisasi mutu sepanjang alur proses produksi dan batas tingkat defect output kurang dari 2\%. Namun pada kenyataannya masih ditemukan produk yang tidak sesuai standar mutu. Penelitian ini bertujuan untuk mengidentifikasi, menganalisis defect, dan menentukan skenario perbaikan kualitas sepanjang lini produksi Pipa PVC. Metode Seven Tools dan Failure Mode and Effect Analysis (FMEA) digunakan sebagai pendekatan dalam menyelesaikan permasalahan defect pada lini produksi Pipa PVC. Hasil penelitian menunjukkan terdapat 3 jenis kecacatan yaitu bercak/bintik, sink mark, dan scratch/goresan. Hasil control chart menunjukkan jumlah produk defect masih dalam batas kontrol artinya perusahaan masih mampu mengontrol kecacatan dengan baik. Selanjutnya dari hasil Cause and effect diagram menunjukkan 3 faktor yang mempengaruhi tingginya defect yaitu manusia, bahan baku dan mesin. Kemudian langkah selanjutnya yaitu analisis faktor kecacatan dengan menggunakan metode FMEA. Dari hasil analisis dan perhitungan RPN tertinggi 147 yaitu faktor manusia dengan jenis kecacatan bercak/bintik dan penyebab kecacatan operator lelah sehingga proses produksi kurang terkontrol.
\end{abstract}

\section{Kata Kunci: Kualitas, Kecacatan, Seven Tools, FMEA, RPN, PVC}

\section{Pendahuluan}

Perkembangan industri saat ini semakin pesat sehingga perusahaan selalu dituntut dan diharapkan mampu untuk menghasilkan produk yang berkualitas tinggi dan sesuai dengan fungsinya (Farid \& Suhartini, 2019). Pencapaian tujuan dilakukan tinjauan atau evaluasi terhadap proses produksi yang ada pada perusahaan, apabila pada proses 
produksi terdapat masalah, maka yang menjadi parameter dilihat dari jumlah defect yang dihasilkan dalam proses produksi. Produk defect merupakan barang yang dibuat dalam proses produksi dan tidak sesuai stanadar yang ditetapkan. Produk defect adalah produk yang tidak memenuhi spesifikasi (Isma \& Hariswan, 2018).

PT. AZ merupakan perusahaan yang bergerak dibidang manufaktur produksi Pipa PVC di Kabupaten Gresik, Jawa Timur. Perusahaan memproduksi berbagai jenis pipa PVC mulai dari ukuran kecil hingga pipa besar. Perbaikan terus menerus pada proses produksi merupakan salah satu pendekatan penjaminan mutu perusahaan manufaktur atau perusahaan jasa (Suparjo, 2019). Perusahaan ini mampu memproduksi pipa \pm 1400 pes per bulan. Tahapan proses produksi pipa PVC yaitu pengadaan bahan baku, mixing, hoppering, extruding, cooling, hold off, printing cutting inspeksi dan jika produk all good inspection selanjutnya barang disimpan di gudang untuk dilakukan pengiriman pada konsumen.

Perusahaan menetapkan standarisasi pengendalian mutu di lini produksi, yaitu jumlah defect produk tidak melebihi $2 \%$. Namun setiap proses produksi terkadang apa yang diinginkan tidak sesuai dengan kenyataan, sehingga data perusahaan menunjukkan tingkat defect yang lebih tinggi dibandingkan standar mutu yang ditetapkan. Tabel. 1 merupakan data produksi selama bulan September sampai Desember 2018.

Tabel 1. Outtput Produksi Sept-Dec 2018

\begin{tabular}{lcc}
\hline Bulan & $\begin{array}{l}\text { Jumlah } \\
\text { Produksi (X) }\end{array}$ & $\begin{array}{l}\text { Jumlah } \\
\text { Defect (Y) }\end{array}$ \\
\hline Sept & 14.012 & 351 \\
\hline Okt & 14.461 & 307 \\
\hline Nov & 14.039 & 370 \\
\hline Des & 14.471 & 398 \\
\hline Jumlah & 56.983 & 1426 \\
\hline $\begin{array}{l}\text { Persentase } \\
(\%)\end{array}$ & & $2.5 \%$ \\
\hline
\end{tabular}

Dari Tabel. 1 diketahui data produksi selama 4 bulan September sampai desember dengan jumlah produksi sebanyak 56983 pipa dengan jumlah kecacatan 1426 pipa artinya hanya $2,5 \%$ rasio kecacatan dari total produksi. Perusahaan telah menetapkan batas kecacatan produksi yaitu sebanyak 2\%, Divisi Quality Control secara terus menerus berupaya meminimalisir jumlah produk outspect agar target kualitas dapat terpenuhi sehingga kerugian akibat produk defect dapat dihilangkan. Pada proses produksi perusahaan manufaktur seperti PT. AZ, terdapat lima faktor yang mempengaruhi terjadinya kecacatan tersebut yaitu mesin, metode kerja, bahan baku, modal, mesin produksi. Namun dari faktor-faktor tersebut belum diketahui secara spesifik yang menyebabkan kecacatan produk yang paling besar.

Penelitian ini bertujuan untuk mengidentifikasi, menganalisis defect, dan menentukan skenario perbaikan kualitas sepanjang lini produksi Pipa PVC guna meminimalisasi defect produk. Metode Statistical Quality Control (SQC) dan metode Failure Mode and Effect Analysis (FMEA) dikenal sebagai metode pengendalian kualitas dan terbukti mengidentifikasi potensi kegagalan yang akan timbul dengan meminimisasi risiko kecacatan (Andrian, Muhammad, \& Petrus, 2020). FMEA merupakan alat analisis untuk mengidentifikasi, mengenali dan mengurangi kegagalan, masalah, kesalahan yang diketahui sehingga masalah yang terjadi pada proses serta produk dapat dicegah dimana FMEA akan meningkatkan kualitas dari produk dan pelayanan sehingga akan meningkatkan kepuasan konsumen (Dini \& Evi, 2019). Metode ini juga dapat digunakan sebagai alat ukur skala prioritas perbaikan dari tiap mode kegagalan yang terjadi sehingga memudahkan langkah perbaikan (Ayu \& Nina, 2021). Seven tools adalah alat-alat yang dapat dipakai untuk peningkatan pengendalian kualitas. Seringkali juga sebagai pemecah masalah, sehingga berbagai lini produksi dapat menggunakan metodologi dalam problem solving tersebut untuk melakukan perbaikan (Faisal \& Syarif, 2017).

Seven Tools dan FMEA merupakan pendekatan yang digunakan dalam menganalisis permasalahan yang teridenifikasi di lini produksi. Pertama yaitu Mengidentifikasi Jenis dan kriteria defect sepanjang alur proses produksi PVC. Kemudian Menghitung kecacatan yang terjadi menggunakan pendekatan seven tools dan FMEA, setalah dilakukan perhitungan maka selanjutnya yaitu menganalisis hasil perhitungan pendekatan seven tools dan FMEA. Terakhir Memberikan usulan perbaikan produk defect pada proses produksi pipa PVC. 
Seven tools digunakan sebagai alat bantu untuk mengendalikan kualitas. Kemampuan seven tools dalam mengemukakan fakta ataupun fenomena yang menyebabkan alat bantu ini banyak digunakan oleh para pakar untuk mengendalikan kualitas. Adapun 7 tools pada pengendalian kualitas yaitu sebagai berikut: (Vera \& Melany, 2021)

1. Diagram Pareto (Pareto Diagram) digunakan sebagai alat untuk mengelola kealahan, masalah atau reject agar dapat memusatkan titik kesalahan untuk melakukan perbaikan (Andrianto \& Nina, 2021).

2. Lembar Periksa (Check Sheet) merupakan alat lembar pengumpulan data yang digunakan untuk memudahkan dan menyederhanakan pencatatan data (Andrianto \& Nina, 2021).

3. Diagram Batang (Histogram) merupakan suatu diagram batang yang digunakan untuk menampilkan atau menyajikan variasi suatu data (Tio \& Mujiya, 2018).

4. Diagram Alur (Flow Chart) adalah alat yang digunakan untuk memberi Gambaran suatu alur atau langkah-langkah yang diperlukan untuk menyelesaikan suatu tugas (Andi \& Tuwanku, 2015).

5. Diagram Tebar (Scatter Diagram) alat yang digunakan untuk melihat penyebaran data dari hubungan dua faktor, dependen dan independen (Vera \& Melany, 2021).

6. Peta Kendali (Control Chart) merupakan alat yang digunakan untuk menentukan batas produk apakah dalam kondisi terkontrol atau di luar batas kendali (Wahyu, Suyadi, \& Choirul, 2017).

7. Diagram Tulang Ikan (Fishbone DiagramDiagram Sebab Akibat) alat yang digunakan untuk mengetahui sebab akibat permasalahan serta untuk mengidentifikasi permasalahan tersebut (Wahyu, Suyadi, \& Choirul, 2017).

FMEA merupakan suatu oendekatan yang digunakan guna mengidentikasi kegagalan yang mungkin terjadi, memberi skala prioritas dari setiap jenis kegagalan dan melakukan tindakan perbaikan pada proses di industry manufaktur dan jasa (Habulloh \& Dwi, 2017).

Tujuan penggunaan FMEA adalah untuk menghilangkan atau mengurangi risiko bahaya terutama untuk prioritas risiko tertinggi dengan menentukan tindakan yang dilakukan di awal. Prioritas risiko ditentukan dari nilai risiko dalam bentuk Risk Priority Number (RPN) dengan beberapa faktor. Risiko kegagalan dan akibatnya ditentukan oleh tiga faktor yaitu (Yasarah \& Ida, 2021):

1. Tingkat keparahan dari kegagalan jika terjadi (severity) merupakan penilaian keseriusan efek potensi kegagalan yang meliputi komposesn, sub-sistem, sistem atau pelanggan jika itu terjadi. Nilai severity 1 sampai 10 , dengan 1 yaitu tidak ada dan 10 yaitu paling parah (Tiara \& Elisabeth, 2016).

2. Frekuensi kegagalan yang terjadi (occurrence) adalah kesempatan bahwa salah satu penyebab/mekanisme spesifik akan terjadi. Kriteria occurrence 1 sampai 10, dengan 1 adalah setidaknya kemungkinan dan 10 aalah tertinggi kemungkinan (Tiara \& Elisabeth, 2016).

3. Kemungkinan kegagalan untuk terdeteksi sebelum kejadian (detection) adalah penilaian kemungkinan bahwa proses kintrol yang diusulakn saat ini akan mendeteksi potensi kelemahan atau kegagalan berikutnya pada saat proses produksi. Nilai detection 1 sampai 10, dengan 1 adalah sangat berpengaruh dan 10 adalah tidak berpengaruh (Tiara \& Elisabeth, 2016).

Meskipun metode SPC dan FMEA telah dilakukan di penelitian terdahulu, namun terdapat perbedaan pada penelitian ini terhadap penelitian terdahulu. Penelitian menggunakan metode SPC dan FMEA di produsen pipa belum dikembangkan pada penelitian sebelumnya. Keutamaan penelitian ini yaitu penerapan seven tools mampu mendeteksi produk outspect dapat di deteksi di sepanjang alur produksi, dan hasil FMEA memiliki keunggulan dalam menganalisis sekaligus merekomendasikan skenario mengeliminasi defect sehingga kerugian akibat produk outspect dapat di minimalisir. Produk Pipa PVC jika dinyatakan no-good maka tidak dapat dilakukan repairement, sehingga produk reject tersebut harus dihancurkan.

\section{Bahan dan Metode}

Studi lapangan dilakukan di perusahaan PT. AZ untuk menggali dan mengumpulkan data. Data yang digunakan yaitu selama 4 bulan (September - Desember) 2018. Selama studi lapangan juga dilakukan studi pustaka dengan melakukan pengumpulan refenrensi baik terhadap buku, literatur, 
catatan, maupun jurnal untuk membatu penelitian. Kemudian dilakukan identifkasi masalah dan perumusan masalah yang didapat dari survey lapangan masalah jenis-jenis defect, penyebab defect yang menyebabkan penurunan kualitas produk. 3 responden penelitian dengan jabatan sebagai Kepala Divisi Quality Control, Kepala Produksi, dan Kepala PPIC merupakan responden dalam pengisian kuesioner FMEA dan brainstorming dalam penyusunan skenario rekomendasi dalam perbaikan kualitas berkelanjutan.

Penelitian ini menggunakan metode explanatory dengan menerapkan dan teori empiris untuk di implementasikan pada studi kasus dengan obyek perusahaan manufaktur produsen Pipa PVC. 4 tahapan penelitian dijabarkan di 2.1 sampai 2.4 sebagai berikut:

\section{Implementasi Metode Seven tools}

Setalah dilakukan obeservasi dan penelusuran dalam pembuatan pipa PVC tipe D4 di PT. AZ data yang telah dikumpulkan yaitu data historis perusahaan dan data hasil observasi langsung selanjutnya di analisis menggunakan metode seven tools yaitu check sheet, flow diagram, scatter plot, histogram, pareto, control chart, dan fishbone diagram/diagram tulang ikan.

\section{Check Sheet}

Pada proses produksi pipa pvc tipe $\mathrm{d} 4$ selama proses tersebut dilakukan pencatatan data menggunakan check sheet. Data yang digunakan selama 4 bulan mulai september sampai desember 201.

\section{Flow Diagram}

MengGambarkan tahapan proses produksi pembuatan Pipa PVC mulai dari bahan baku sampai produk jadi.

\section{Scatter Diagram}

Untuk mengetahui korelasi antara variabel $\mathrm{x}$ dan variabel y pada produksi pipa pve tipe d4 dilakukan analisis scatter plot. Scatter plot dibuat menggunakan MS. Excel yang hasilnya berupa diagram scatter.

\section{Histogram}

Data yang ada pada check sheet kemudian diolah dalam diagram histogram untuk mengetahui karakteristik atau variasi data defect tersebut.

\section{Pareto}

Data yang ada diolah dalam bentuk diagram pareto untuk mengatahui jenis defect terbesar hingga terkecil.

\section{Control chart / P chart}

Jenis data yang digunakan merupakan data atribut sehingga digunakan peta kendali P (pchart). Perhitungan dilakukan dengan menggunakan MS. Excel data-data primer dimasukkan untuk menghitung p-bar (nilai tengah), LCL (nilai batas bawah), dan UCL (nilai batas atas).

\section{Diagram Tulang Ikan}

Selanjutnya yaitu analisis penetuan sebab akibat hubungan antara masalah dengan faktor kemungkinan yang menyebabkan terjadinya masalah. Faktor-faktor yang diidentifikasi antara lain yaitu bahan baku, mesin, manusia, metode dan lingkungan.

\section{Implementasi Metode FMEA}

\section{Penentuan Nilai Efek Kecacatan (Severity)}

Jenis kecacatan yang terjadi selama proses produksi dipengaruhi beberapa factor utama antara lain : bahan baku, mesin, manusia, metode. Pemberian nilai efek kecacatan dilakukan oleh responden melalui brainstorming dan pengisian kuesioner FMEA kepada operator, QC, atau kepala produksi. Dari hasil wawancara tersebut didapatkan nilai efek kecacatan / Severity (S). semakin besar nilai yang diberikan maka semakin besar dampak yang dihasilkan (Erwindasari, Nurwidiana, \& Brav, 2019). Nilai severity 1 sampai 10, dengan 1 yaitu tidak ada dan 10 yaitu paling parah (Tiara \& Elisabeth, 2016).

\section{Penentuan Nilai Peluang Defect (Occurrence)}

Setelah dilakukan penetuan nilai efek kecacatan selanjutnya yaitu dilakukan penetuan nilai peluang kecacatan / Occurrence (O). Proses penilaian sama dilakukan oleh perusahaan dengan proses wawancara. Semakin besar nilai yang diberikan makan semakin besar dampak yang dihasilkan (Erwindasari, Nurwidiana, \& Brav, 2019). Kriteria occurrence 1 sampai 10 , dengan 1 adalah setidaknya kemungkinan dan 10 adalah tertinggi kemungkinan (Tiara \& Elisabeth, 2016).

\section{Penentuan Nilai Deteksi Kecacatan} (Detection)

Proses selanjutnya yaitu penetuan nilai deteksi kecacatan. Proses penilaian dilakukan oleh perusahaan dengan melakukan wawancara kepada mandor, QC, atau kepala produksi. Semakin kecil nilai yang diberikan makan 
semakin besar pengaruh yang dihasilkan (Erwindasari, Nurwidiana, \& Brav, 2019). Nilai detection 1 sampai 10 , dengan 1 adalah sangat berpengaruh dan 10 adalah tidak berpengaruh (Tiara \& Elisabeth, 2016).

\section{Perhitungan RPN}

Langkah berikuntya yang dilakukan setelah metode FMEA adalah menghitung nilai RPN. Perhitungan ini dilakukan untuk mengetahui moda kegagalan yang harus diutamakan dalam penanganannya. Nilai RPN dapat diketahui dengan mengalikan nilai severity, occurance, dan detection yang telah diperoleh sebelumnya. Nilai RPN paling tinggi diutamakan dalam pemberian rekomendasi (Erwindasari, Nurwidiana, \& Brav, 2019).

RPN $=$ saverity $\mathrm{X}$ occurance $\mathrm{X}$ detection (Erwindasari, Nurwidiana, \& Brav, 2019).

\section{Skenario Perbaikan}

Perbaikan dilakukan berdasarkan nilai RPN tertinggi dengan priorotas penanganan kecacatan (Erwindasari, Nurwidiana, \& Brav, 2019). Dari usulan perbaikan tersebut bisa dilakukan analisis lagi atau mengkombinaksikan dengan metode lain seperti metode DMAIC atau metode six sigma untuk mendapatkan hasil yang lebih baik dan lebih maksimal lagi untuk perusahaan dan untuk penelitian.

\section{Hasil dan Pembahasan}

\section{Jenis Defect}

Dari hasil pengamatan di PT. AZ divisi pipa PVC/HDPE \& Fitting selama 4 bulan pada bulan September sampai desember 2018 didapatkan 3 jenis kecacatan yang di alami pada saat poduksi pipa PVC tipe D4 inch di Gambar 1.

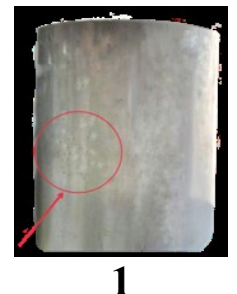

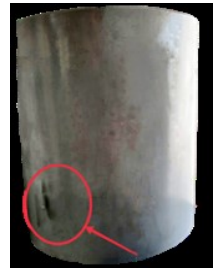

2

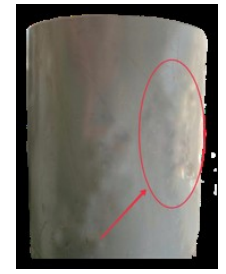

3
Gambar 1. Jenis kecacatan produk pipa

Defect bercak atau bintik adalah defect yang terlihat pada permukaan pipa, permukaan tidak pipa halus karena terdapat bintik bintik kecil akibat proses produksi yang tidak sempurna.

Scratch/goresan sama halnya dengan defect bintik yaitu defect yang terdapat pada permukaan pipa, bedanya ini seperti goresan panjang yang terjadi pada saat produksi.

Sink mark adalah cekungan cekungan pada pipa yang membuat pipa terlihat seperti penyok dan tidak silindris.

I. Data Kecacatan Produk / Check Sheet Data kecacatan yang di ambil yaitu Bulan September - Desember 2018. diketahui bahwa total produksi pipa selama 4 bulan yaitu sebanyak 56983 pcs dan terdapat 3 jenis kecacatan antara lain bercak/bintik sebanyak 745 pcs, Sink mark 268 pcs, Scratch/goresan sebanyak 413 pcs. Jadi jumlah kecacatan yaitu sebanyak 1426 pcs. Diketahui terdapat 2.5\% kecacatan dari seluruh jumlah produksi.

Tabel 2. Data Kecacatan Produk

\begin{tabular}{cccccc}
\hline Bulan & $\begin{array}{c}\text { Jumlah } \\
\text { Produksi } \\
(\mathbf{X})\end{array}$ & \multicolumn{3}{c}{ Jenis Defect } & Jumlah \\
\cline { 3 - 5 } & 14012 & 179 & 68 & 104 & 351 \\
\hline Sept & $14 n$ Defect & $\begin{array}{c}\text { Sink } \\
\text { Marks }\end{array}$ & Scratch & (Y) \\
\hline Okt & 14461 & 163 & 61 & 83 & 307 \\
\hline Nov & 14039 & 192 & 68 & 110 & 370 \\
\hline Des & 14471 & 211 & 71 & 116 & 398 \\
\hline Jumlah & 56983 & 745 & 268 & 413 & 1426 \\
\hline$\%$ & & & & & $2.5 \%$ \\
\hline$\%$
\end{tabular}

\section{Flow chart / Run chart}

Flow Chart produksi proses proses produksi dan inspeksi Pipa PVC dapat dilihat di Gambar 2 flow chart produksi pipa PVC.

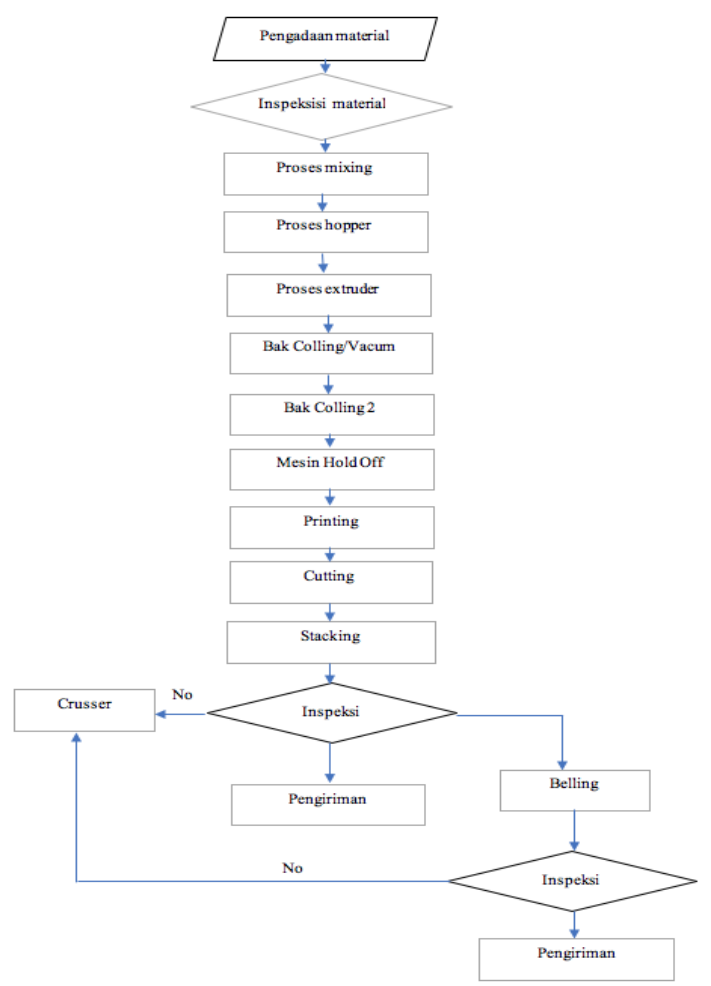

Gambar 1. Flow Chart Produksi Pipa PVC 
Gambar 2. merupakan alur proses produksi pipa PVC. Sebelum mulai proses produksi pertama adalah pengadaan bahan baku setelah bahan baku datang dilakukan inspeksi, setelah lolos maka akan dilakukan prose mixing bahan baku pipa kemudian hasil mixing akan dimasukkan mesin hopper melalui crane. Proses selanjutnya yaitu masuk mesin extruder pada proses ini pipa mulai di bentuk lalu masuk mesin vacum/bak cooling 1 dan bak coolling 2 untuk di dinginkan, setelah mesin bak colling yaitu ada mesin hold off yang berfungsi sebagai mesin penarik pipa.

Kemudian setelah keluar dari mesin hold off proses selanjutnya yaitu proses printing untuk memberi merk dan spesifikasi pipa, lalu dilakukan cutting sesuai panjang pipa. Setelah cutting pipa akan melalui mesin stacking dan akan dilakukan inspeksi akhir. setelah inspeksi akhir ada 3 tahap yang dilalui, pertama apabila tidak lolos maka pipa akan dipisah dan dimasukan mesin crusser untuk dihancurkan. Tahap kedua apabila lolos maka pipa akan masuk gudang penyimpanan dan dilakukan pengiriman. Tahap etiga apabila lolos inspeksi dan ingin dilakukan pembuatan ujung sambungan pipa maka akan masuk proses selanjutnya yaitu proses belling, setelah proses belling dilakukan inspeksi lagi apabila lolos inspeksi maka pipa akan masuk gudang penyimpanan lalu dilakukan pengiriman dan apabila tidak lolos inspeksi maka pipa akan masuk mesin crusser untuk dihancurkan dan dilakukan proses produksi ulang.

\section{Scatter Plot}

Dari hasil pengamatan, berikut merupakan hasil Scatter Plot yang menunjukkan hungan antara jumlah produksi dengan jumlah kecacatan produk.

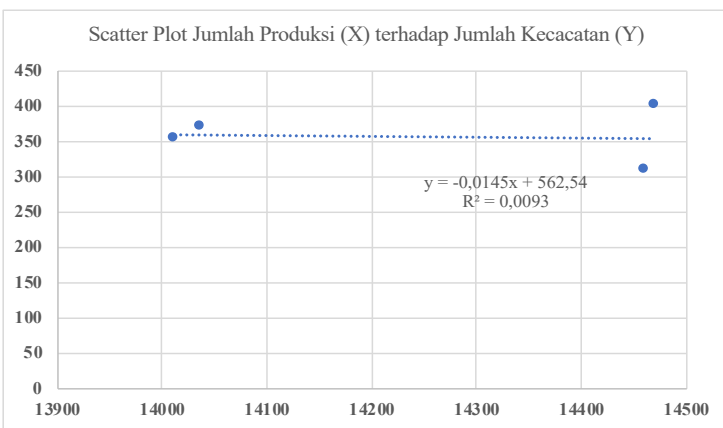

Gambar 3. Scatter plot jumlah produksi (X) terhadap jumlah kecacatan (Y)

Dapat diketahui dari Gambar 3. bahwa menunjukkan adanya kolerasi rendah (low moderat) antara variabel $\mathrm{x}$ dan variabel $\mathrm{y}$. Di katakan korelasi rendah karena titik koordinat saling berjauhan dan tidak berdekatan pada satu garis/kurva.

\section{Histogram}

Data histogram ini digunakan untuk mengetahui penyebaran jenis defect pada produk secara menyeluruh sehingga dapat diketahui jenis kecacatan produk yang paling sering terjadi pada produk pipa PVC tipe D 4 dan ata histogram ini merupakan data selama 4 bulan mulai September sampai Desember 2018.

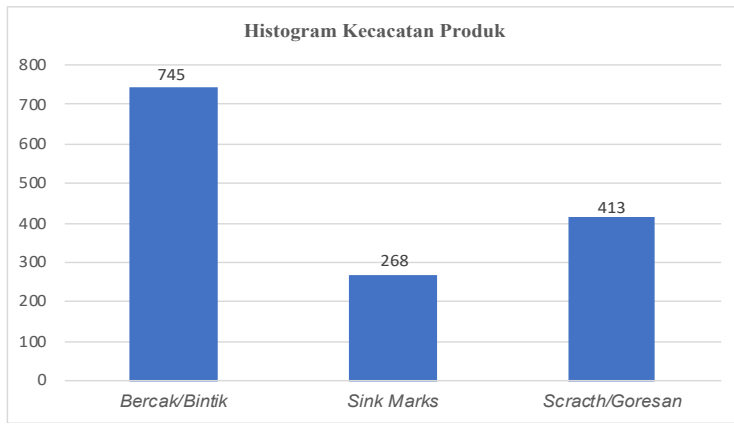

Gambar 4. Histogram Kecacatan Produk Pipa

Dari data Histogram Gambar 4. diatas dapat diketahui bahwa kecacatan yang paling sering terjadi yaitu bercak/bintik pada pipa (745), kemudian yang kedua yaitu scratch/goresan (413), dan yang paling sedikit yaitu sink marks atau permukaan tidak rata pada pipa (268).

\section{$V$. Diagram Pareto}

Diagram pareto digunakan untuk mengetahui jenis defect yang paling sering terjadi beserta dengan persentasenya.

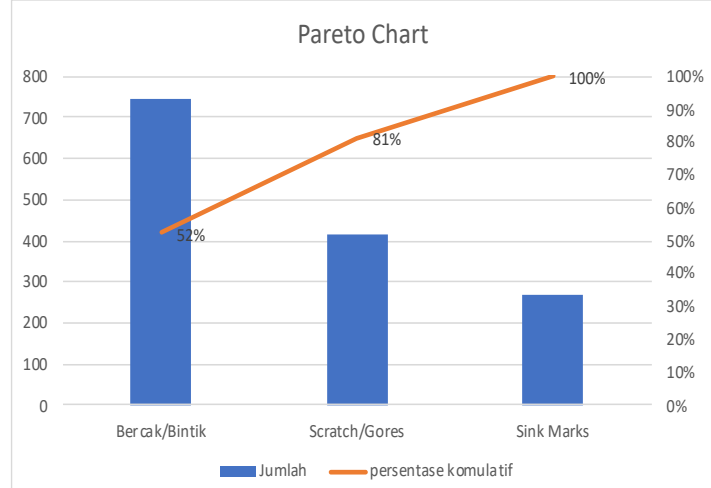

Gambar 5. Pareto chart

Dari Gambar 5. dapat dilihat bahwa jenis kecacatan yang paling sering terjadi yaitu bercak/bintik dengan persentase 52\% dari keseluruhan jumlah kecacatan. Kemudian scratch/gores dengan presentase $29 \%$ total 
komulatif $81 \%$ dan sink mark dengan presentase $19 \%$ jadi total kumulatif $100 \%$.

\section{Control chart / P Chart}

Contol chart atau peta kendali digunakan untuk melihat apakah proses pegendalian kualitas oleh perusahaan sudah terkendali atau tidak. Jenis cacat adalah data atribut (bercak/bintik, sink mark, scratch/gores) sehingga peta kendali yang digunakan adalah peta kendali khusus data atribut yaitu $\mathrm{P}$ chart.

Tabel 5. Data Proporsi Kecacatan

\begin{tabular}{|c|c|c|c|c|c|c|}
\hline Bulan & $\begin{array}{l}\text { Jumlah } \\
\text { Produksi }\end{array}$ & $\begin{array}{c}\text { Jumlah } \\
\text { Defect }\end{array}$ & Proporsi & Cl & Ucl & Lel \\
\hline Sept & 14012 & 351 & 0,025 & 0,025 & 0,029 & 0,02 \\
\hline Okt & 14461 & 307 & 0,021 & 0,025 & 0,029 & 0,02 \\
\hline Nov & 14039 & 370 & 0,026 & 0,025 & 0,029 & 0,02 \\
\hline Des & 14471 & 398 & 0,028 & 0,025 & 0,029 & 0,02 \\
\hline Jumlah & 56983 & 1426 & & & & \\
\hline$\rho$ & 0,025 & & & & & \\
\hline $1-\rho$ & 0,975 & & & & & \\
\hline
\end{tabular}

nilai rata-rata $\mathrm{p}$ :

$\bar{p}=\frac{\text { total produk cacat }}{\text { total produk di inspeksi }}$

Menghitung batas CL,UCL,LCL

$$
\begin{aligned}
& C L=\bar{p} \ldots \ldots \ldots \ldots \ldots \ldots \ldots \ldots \ldots \\
& U C L=\bar{p}+3 \sqrt{\frac{\bar{p}(1-\bar{p})}{n}} . \\
& L C L=\bar{p}-3 \sqrt{\frac{\bar{p}(1-\bar{p})}{n}} .
\end{aligned}
$$

Ket :

$\mathrm{p}=$ proporsi kesalahan dalam setiap sampel $\mathrm{n}=$ banyaknya sampel yang diambil dalam inspeksi

$\mathrm{CL}=$ control limit

$\mathrm{UCL}=$ Upper control limit

$\mathrm{LCL}=$ Lower control limit

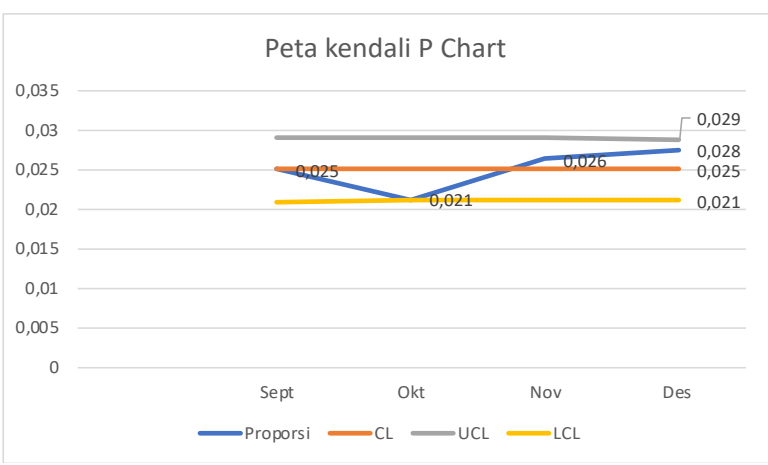

Gambar 6. Peta kendali P chart
Dari hasil analisis control chart / peta kendali diketahui bahwa tidak ada data yang outlier atau keluar dari batas UCL maupun LCL sehingga dapat di simpulkan bahwa pengendalian kualitas oleh perusahaan masih cukup terkedali.

\section{VII.Diagram Sebab Akibat / Diagram Tulang Ikan}

Berikut ini merupakan diagram sebab akibat yang digunakan untuk menganalisa penyebab permasalahan kecacatan yang terjadi pada produksi Pipa PVC tipe D4 di PT. AZ.

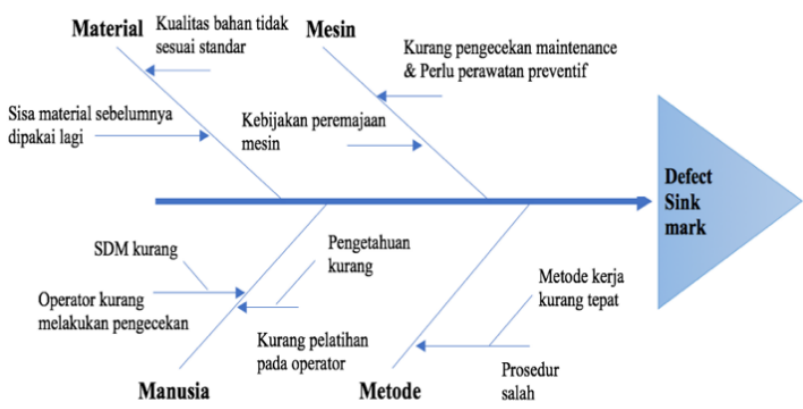

Gambar 7. Fishbone kecacatan Sink mark.

Dari Gambar. 7 teridentifikasi 4 faktor yang memoengaruhi kecacatan Sink mark yaitu bahan baku, mesin, manusia, dan metode.

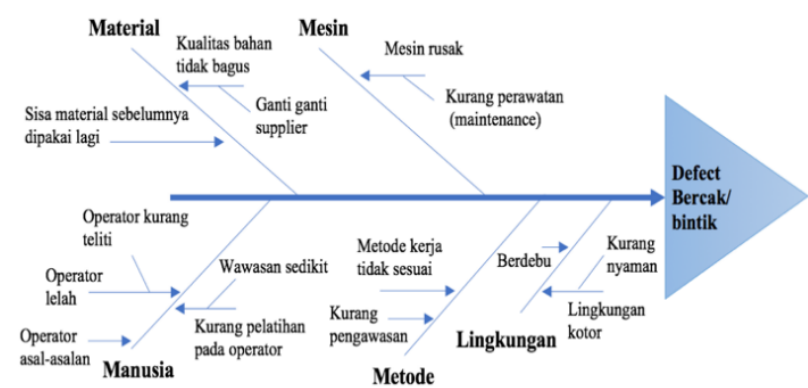

Gambar 8. Fishbone kecacatan bercak/bintik.

Dari Gambar 8. dapat diketahui bahwa ada 5 faktor yang mempengaruhi kecacatan bercak/bintik, antara lain bahan baku, mesin, manusia, metode, dan lingkungan. Ditinjau dari 5 faktor tersebut faktor manusia lah yang sangat mempengaruhi kecacatan produk. 


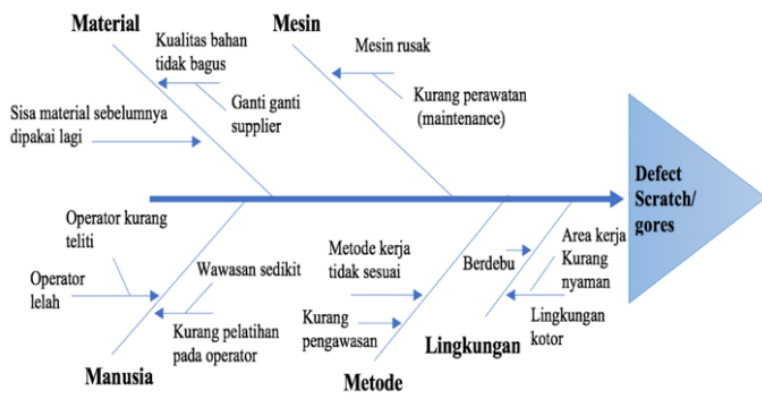

Gambar 9. Fishbone kecacatan Scratch/goresan.

Dari Gambar 9. dapat diketahui bahwa terdapat 5 faktor yang mempengaruhi kecacatan Scratch/goresan pada pipa yaitu faktor metrial, mesin, manusia, metode dan lingkungan. Dari beberapa faktor tersebut faktor manusia merupakan faktor yang sangat mempengaruhi kecacatan. Hasil Diagram Fishbone dari ketiga defect ini akan dijadikan sebagai input data dalam pengerjaan metode FMEA.

\section{Failure Mode And Effect Analysis (FMEA)}

Tabel. 6 merupakan hasil perhitungan FMEA dengan melakukan penentuan nilai severity $(\mathrm{S})$, occurrence $(\mathrm{O})$, detection $(\mathrm{D})$. Nilai dari $\mathrm{S}$ $\mathrm{O}$ D tersebut di dapat dari penyebaran kuesioner yang telah dilakukan sesuai tahapan penelitian. Hasil rekapitulasi FMEA kecacatan Sink mark. Sehingga hasil rekapitulasi didapatkan nilai Severity, Occurrence, Detection, dari nilai Severity faktor yang dianggap paling berdampak yaitu faktor manusia dengan skor 7, kemudian Occurrence faktor yang paling berdampak yaitu faktor manusia dengan skor 6, dan untuk Detection pengaruh yang paling besar yaitu juga dari faktor manusia dengan skor 3 .

Tabel 6. Nilai S O D Dan RPN

\begin{tabular}{|c|c|c|c|c|c|c|c|}
\hline $\begin{array}{l}\text { Jenis } \\
\text { Defect }\end{array}$ & $\begin{array}{l}\text { Akibat } \\
\text { Dari } \\
\text { Defect }\end{array}$ & $\begin{array}{l}\text { Fakt } \\
\text { or }\end{array}$ & $\begin{array}{l}\text { Penyebab } \\
\text { Defect }\end{array}$ & & $O$ & $D$ & $\gtrless$ \\
\hline \multirow{4}{*}{ 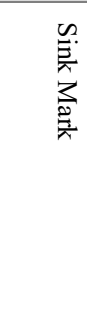 } & \multirow{4}{*}{ 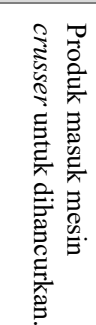 } & \multirow{2}{*}{ 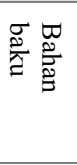 } & $\begin{array}{l}\text { Bahan Tidak } \\
\text { Sesuai Estándar. }\end{array}$ & 3 & 4 & 5 & 60 \\
\hline & & & $\begin{array}{lr}\text { Sisa } & \text { Bahan } \\
\text { baku } & \text { Di Pakai } \\
\text { Lagi } & \end{array}$ & 2 & 2 & 6 & 24 \\
\hline & & \multirow{2}{*}{ 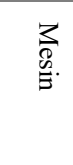 } & $\begin{array}{l}\text { Perlu Perawatan } \\
\text { Preventif. }\end{array}$ & 4 & 3 & 4 & 48 \\
\hline & & & $\begin{array}{l}\text { Kebijakan } \\
\text { Peremajaan } \\
\text { Mesin }\end{array}$ & 2 & 3 & 5 & 30 \\
\hline
\end{tabular}

\begin{tabular}{|c|c|c|c|c|c|c|c|}
\hline & & 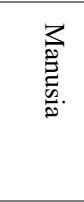 & $\begin{array}{l}\text { Operator } \\
\text { Kurang } \\
\text { Melakukan } \\
\text { Pengecekan. } \\
\text { Kurang Pelatiha } \\
\text { Pada Operator. }\end{array}$ & 6 & 6 & 3 & 108 \\
\hline & & $\begin{array}{l}\text { Meto } \\
\text { de }\end{array}$ & $\begin{array}{l}\text { Metode Kerja } \\
\text { Kurang Tepat }\end{array}$ & 3 & 3 & 5 & 45 \\
\hline \multirow[t]{5}{*}{ 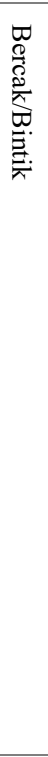 } & \multirow{5}{*}{ 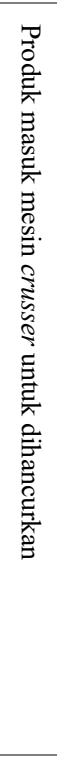 } & $\begin{array}{l}\text { Baha } \\
\text { n } \\
\text { baku }\end{array}$ & 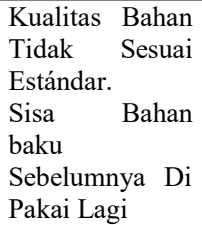 & 3 & 4 & 5 & 60 \\
\hline & & $\begin{array}{l}\text { Mesi } \\
n\end{array}$ & $\begin{array}{l}\text { Kurang } \\
\text { Perawatan / } \\
\text { Maintenance } \\
\text { Mesin }\end{array}$ & 4 & 4 & 4 & 64 \\
\hline & & Men & $\begin{array}{l}\text { Operator Lelah } \\
\text { Tidak Sesuai } \\
\text { Prosedur } \\
\text { Kurang } \\
\text { Pelatihan }\end{array}$ & $\begin{array}{l}7 \\
5\end{array}$ & $\begin{array}{l}7 \\
6\end{array}$ & $\begin{array}{l}3 \\
4\end{array}$ & $\begin{array}{l}147 \\
125\end{array}$ \\
\hline & & $\frac{3}{\frac{8}{2}}$ & $\begin{array}{l}\text { Metode Kerja } \\
\text { Kurang Tepat } \\
\text { Kurang } \\
\text { Pengawasan }\end{array}$ & 3 & 3 & 4 & 18 \\
\hline & & $\begin{array}{l}\text { Ling } \\
\text { kung } \\
\text { an }\end{array}$ & $\begin{array}{l}\text { Berdebu } \\
\text { Lingkungan } \\
\text { Kotor. }\end{array}$ & $\begin{array}{l}4 \\
4\end{array}$ & $\begin{array}{l}3 \\
3\end{array}$ & $\begin{array}{l}5 \\
4\end{array}$ & $\begin{array}{l}64 \\
36\end{array}$ \\
\hline \multirow[t]{5}{*}{ 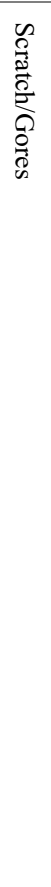 } & \multirow{5}{*}{ 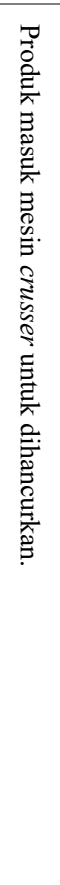 } & 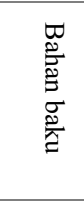 & $\begin{array}{l}\text { Ganti-Ganti } \\
\text { Supplier. } \\
\text { Sisa Bahan } \\
\text { baku } \\
\text { Sebelumnya Di } \\
\text { Pakai Lagi }\end{array}$ & 3 & 3 & 4 & $\begin{array}{l}48 \\
36\end{array}$ \\
\hline & & $\begin{array}{l}3 \\
0 \\
0 . \\
0\end{array}$ & $\begin{array}{l}\text { Perlu Perawatan } \\
\text { Preventif. } \\
\text { Kebijakan } \\
\text { Peremajaan } \\
\text { Mesin }\end{array}$ & 4 & 3 & 5 & $\begin{array}{l}60 \\
64\end{array}$ \\
\hline & & Men & $\begin{array}{l}\text { Operator } \\
\text { Kurang } \\
\text { Melakukan } \\
\text { Pengecekan. } \\
\text { Kurang Pelatiha } \\
\text { Pada Operator. }\end{array}$ & 7 & 6 & 3 & 126 \\
\hline & & $\begin{array}{l}\text { Meto } \\
\text { de }\end{array}$ & $\begin{array}{l}\text { Metode Kerja } \\
\text { Kurang Tepat } \\
\text { Kurang } \\
\text { Pengawasan }\end{array}$ & 3 & 4 & 5 & 60 \\
\hline & & $\begin{array}{l}\text { Ling } \\
\text { kung } \\
\text { an }\end{array}$ & $\begin{array}{l}\text { Area Kerja } \\
\text { Kurang } \\
\text { Nyaman Karena } \\
\text { Panas. } \\
\text { Lingkungan } \\
\text { Kotor. }\end{array}$ & 3 & 3 & 3 & 27 \\
\hline
\end{tabular}

Hasil rekapitulasi FMEA defect Bercak/bintik, dengan nilai Severity tertinggi yaitu faktor manusia dengan skor 7 (sangat berdampak), kemudian Occurrence tertinggi yaitu faktor manusia dengan skor 6 (sangat berdampak, dan Detection skor/nilai terkecil yaitu faktor manusia dengan skor 3 (sangat berpengaruh). Hasil rekapitulasi FMEA kecacatan Scratch/goresan. Dengan nilai Severity tertinggi yaitu faktor manusia dengan skor 7 (sangat berdampak), kemudian 
Occurrence tertinggi yaitu faktor manusia dengan skor 7 (sangat berdampak, dan Detection skor/nilai terkecil yaitu faktor manusia dan lingkungan dengan skor masingmasing 3 (sangat berpengaruh)

Langkah selanjutnya setelah dilakukan perhitungan metode FMEA yaitu dilakukan penetuan nilai RPN (Risk Priority Number). Dari perhitungan tersebut dapat diketahui bahwa dari ke 3 kecacatan tersebut memiliki nilai RPN tertinggi di setiap faktor penyebab kecacatan. Pertama jenis kecacatan sink mark memiliki nilai RPN tertinggi 108 yaitu pada faktor manusia dengan penyebab kecacatan kurang pelatihan pada operator, kedua jenis kecacatan bercak/bintik memiliki nilai RPN tertingi 147 yaitu pada faktor manusia dengan penyebab kecacatan operator lelah, ketiga scratch/goresan memiliki nilai RPN tertinggi 126 yaitu pada faktor manusia dengan penyebab kecacatan operator kurang melakukan pengecekan.

Tabel 7. merupakan usulan perbaikan dari hasil perhitungan nilai RPN dan di urutkan mulai dari nilai RPN tertinggi ke terendah dengan tingkat penanganan yang segera atau prioritas utama untuk segera dilakukan perbaikan. Sehingga dapat diketahui jenis kecacatan yang menjadi perioritas untuk dilakukan perbaikan yaitu pertama bercak/bintik RPN 147 dengan penyebab kecacatan operator lelah kendali yang dilakukan bergantian dengan operator lain dan menambah SDM, kedua jenis kecacatan scratch/goresan nilai RPN 126 dengan penyebab kecacatan operator kurang melakukan pengecekan dan kendali yang dilakukan melakukan pemantauan oleh kepala produksi atau pihak lain yang terkait masalah proses produksi.

Tabel 7. Usulan Perbaikan

\begin{tabular}{|c|c|c|c|}
\hline $\begin{array}{l}\text { Jenis } \\
\text { Defect }\end{array}$ & $\begin{array}{l}\text { Penyebab } \\
\text { Defect }\end{array}$ & $R P N$ & $\begin{array}{l}\text { Kendali Yang } \\
\text { Dilakukan }\end{array}$ \\
\hline $\begin{array}{l}\text { Bercak/ } \\
\text { Bintik }\end{array}$ & $\begin{array}{l}\text { Operator } \\
\text { lelah }\end{array}$ & 147 & $\begin{array}{l}\text { Perbaikan Shift dan } \\
\text { Menambah SDM }\end{array}$ \\
\hline $\begin{array}{l}\text { Scratch/ } \\
\text { Gores }\end{array}$ & $\begin{array}{l}\text { Operator } \\
\text { kurang } \\
\text { melakukan } \\
\text { pengecekan. }\end{array}$ & 126 & $\begin{array}{l}\text { Melakukan pemantauan } \\
\text { oleh kepala produksi. }\end{array}$ \\
\hline $\begin{array}{l}\text { Bercak/ } \\
\text { Bintik }\end{array}$ & $\begin{array}{l}\text { Oprator } \\
\text { tidak sesuai } \\
\text { prosedur }\end{array}$ & 125 & $\begin{array}{l}\text { Perlu dilakukan } \\
\text { pengawasan }\end{array}$ \\
\hline $\begin{array}{l}\text { Scratch/ } \\
\text { Gores }\end{array}$ & $\begin{array}{l}\text { Kurang } \\
\text { pelatiha pada } \\
\text { operator. }\end{array}$ & 120 & $\begin{array}{l}\text { Diadakan } \\
\text { seminar/pelatihan bagi } \\
\text { operator. }\end{array}$ \\
\hline $\begin{array}{l}\text { Sink } \\
\text { Mark }\end{array}$ & $\begin{array}{l}\text { Kurang } \\
\text { pelatiha pada } \\
\text { operator. }\end{array}$ & 108 & $\begin{array}{l}\text { Mengadakan pelatihan } \\
\text { bagi operator. }\end{array}$ \\
\hline $\begin{array}{l}\text { Sink } \\
\text { Mark }\end{array}$ & $\begin{array}{l}\text { Operator } \\
\text { lalai }\end{array}$ & 105 & Melkukan pemantauan. \\
\hline
\end{tabular}

\begin{tabular}{|c|c|c|c|}
\hline $\begin{array}{l}\text { Bercak/ } \\
\text { Bintik }\end{array}$ & $\begin{array}{l}\text { Kurang } \\
\text { pelatihan }\end{array}$ & 90 & $\begin{array}{l}\text { Diadakan spelatihan bagi } \\
\text { operator. }\end{array}$ \\
\hline $\begin{array}{l}\text { Bercak/ } \\
\text { Bintik }\end{array}$ & $\begin{array}{l}\text { Kurang } \\
\text { perawatan } \\
\text { mesin }\end{array}$ & 64 & $\begin{array}{l}\text { Dilakukan pengecekan } \\
\text { setiap sebulan sekali. }\end{array}$ \\
\hline $\begin{array}{l}\text { Bercak/ } \\
\text { Bintik }\end{array}$ & Berdebu & 64 & $\begin{array}{l}\text { Perlu dilakukan } \\
\text { pembersihat setiap } \\
\text { pergaantian shift. }\end{array}$ \\
\hline $\begin{array}{l}\text { Scratch/ } \\
\text { Gores }\end{array}$ & $\begin{array}{l}\text { Kebijakan } \\
\text { peremajaan } \\
\text { mesin }\end{array}$ & 64 & $\begin{array}{l}\text { Peremajaan mesin setiap } \\
\text { 10thn sekali. }\end{array}$ \\
\hline $\begin{array}{l}\text { Sink } \\
\text { Mark }\end{array}$ & $\begin{array}{l}\text { Bahan tidak } \\
\text { sesuai } \\
\text { standar. }\end{array}$ & 60 & $\begin{array}{l}\text { Menetapkan supplier } \\
\text { bahan baku. }\end{array}$ \\
\hline $\begin{array}{l}\text { Bercak/ } \\
\text { Bintik }\end{array}$ & $\begin{array}{l}\text { Ganti-ganti } \\
\text { supplier }\end{array}$ & 60 & $\begin{array}{l}\text { Menetapkan supplier } \\
\text { bahan baku. }\end{array}$ \\
\hline $\begin{array}{l}\text { Bercak/ } \\
\text { Bintik }\end{array}$ & $\begin{array}{l}\text { Sisa bahan } \\
\text { baku } \\
\text { sebelumnya } \\
\text { di pakai lagi }\end{array}$ & 60 & $\begin{array}{l}\text { Menambahkan campuran } \\
\text { bahan baku. }\end{array}$ \\
\hline $\begin{array}{l}\text { Scratch/ } \\
\text { Gores }\end{array}$ & $\begin{array}{l}\text { Perlu } \\
\text { perawatan } \\
\text { preventif }\end{array}$ & 60 & $\begin{array}{l}\text { Dilakukan pengecekan } \\
\text { setiap sebulan sekali. }\end{array}$ \\
\hline $\begin{array}{l}\text { Scratch/ } \\
\text { Gores }\end{array}$ & $\begin{array}{l}\text { Metode kerja } \\
\text { kurang tepat }\end{array}$ & 60 & $\begin{array}{l}\text { Membuat/memperbarui } \\
\text { SOP. }\end{array}$ \\
\hline $\begin{array}{l}\text { Sink } \\
\text { Mark }\end{array}$ & $\begin{array}{l}\text { Perlu } \\
\text { rawatan } \\
\text { eventif }\end{array}$ & 48 & $\begin{array}{l}\text { Dilakukan pengecekan } \\
\text { setiap sebulan sekali. }\end{array}$ \\
\hline $\begin{array}{l}\text { Scratch/ } \\
\text { Gores }\end{array}$ & $\begin{array}{l}\text { Ganti-ganti } \\
\text { supplier. }\end{array}$ & 48 & $\begin{array}{l}\text { Menetapkan supplier } \\
\text { bahan baku. }\end{array}$ \\
\hline $\begin{array}{l}\text { Sink } \\
\text { Mark }\end{array}$ & $\begin{array}{l}\text { Metode kerja } \\
\text { kurang tepat }\end{array}$ & 45 & $\begin{array}{l}\text { Membuat/memperbarui } \\
\text { SOP }\end{array}$ \\
\hline $\begin{array}{l}\text { Bercak/ } \\
\text { Bintik }\end{array}$ & $\begin{array}{l}\text { Lingkungan } \\
\text { kotor. }\end{array}$ & 36 & $\begin{array}{l}\text { Selain petugas } \\
\text { kebersihan setiap orang } \\
\text { yang ada pada pabrik } \\
\text { menjaga kebersihan. }\end{array}$ \\
\hline $\begin{array}{l}\text { Scratch/ } \\
\text { Gores }\end{array}$ & $\begin{array}{l}\text { Kurang } \\
\text { pengawasan }\end{array}$ & 36 & $\begin{array}{l}\text { Perlu pemantauan oleh } \\
\text { kepala produksi. }\end{array}$ \\
\hline $\begin{array}{l}\text { Scratch/ } \\
\text { Gores }\end{array}$ & $\begin{array}{l}\text { Sisa bahan } \\
\text { baku di } \\
\text { pakai lagi }\end{array}$ & 36 & $\begin{array}{l}\text { Menambahkan campuran } \\
\text { bahan baku. }\end{array}$ \\
\hline $\begin{array}{l}\text { Sink } \\
\text { Mark }\end{array}$ & $\begin{array}{l}\text { Peremajaan } \\
\text { mesin }\end{array}$ & 30 & $\begin{array}{l}\text { Peremajaan mesin setiap } \\
\text { 10thn sekali. }\end{array}$ \\
\hline $\begin{array}{l}\text { Bercak/ } \\
\text { Bintik }\end{array}$ & $\begin{array}{l}\text { Metode kerja } \\
\text { kurang tepat }\end{array}$ & 30 & $\begin{array}{l}\text { Membuat/memperbarui } \\
\text { SOP. }\end{array}$ \\
\hline $\begin{array}{l}\text { Scratch/ } \\
\text { Gores }\end{array}$ & $\begin{array}{l}\text { Area kerja } \\
\text { panas. }\end{array}$ & 27 & $\begin{array}{l}\text { Perlu penambahan } \\
\text { saluran udara / fentilasi. }\end{array}$ \\
\hline $\begin{array}{l}\text { Scratch/ } \\
\text { Gores }\end{array}$ & $\begin{array}{l}\text { Lingkungan } \\
\text { kotor. }\end{array}$ & 27 & $\begin{array}{l}\text { Selain petugas } \\
\text { kebersihan setiap orang } \\
\text { yang ada pada pabrik } \\
\text { menjaga kebersihan. }\end{array}$ \\
\hline $\begin{array}{l}\text { Sink } \\
\text { Mark }\end{array}$ & $\begin{array}{l}\text { Sisa bahan } \\
\text { baku di } \\
\text { pakai lagi }\end{array}$ & 24 & $\begin{array}{l}\text { Menambahkan campuran } \\
\text { bahan baku. }\end{array}$ \\
\hline $\begin{array}{l}\text { Bercak/ } \\
\text { Bintik }\end{array}$ & $\begin{array}{l}\text { Kurang } \\
\text { pengawasan }\end{array}$ & 18 & $\begin{array}{l}\text { Perlu dilakukan } \\
\text { pemantauan oleh kepala } \\
\text { produksi. }\end{array}$ \\
\hline
\end{tabular}

\section{Analisis Implementasi Seven Tools}

Berdasarkan hasil analisis, terdapat 3 jenis kecacatan produk yaitu Bercak/bitnik, Sink Mark, Scratch/Goresan. Dari ketiga jenis kecacatan tersebut jenis kecacatan bercak/bitnik yang paling sering terjadi yaitu sebanyak 745 pcs dalam 4 bulan produksi dan dapat diketahui dari diagram pareto kecacatan bercak/bintik memiliki presentase paling tinggi yaitu $52 \%$ dari total kecacatan. Dari pengolahan data Scatter Plot tidak ada 
pengaruh antara jumlah produksi dengan jumlah kecacatan produk dan juga masih dalam pengendalian batas kecacatan. Kemudian untuk diagaram sebab akibat diketahui bahwa faktor dominan terjadinya kecacatan produk disebabkan oleh faktor manusia (operator). Akibatnya produk masih terjadi kecacatan meskipun semua proses produksi telah menggunakan mesin, seperti pada kecacatan bercak/bitnik dan goresan bisa diakibatkan oleh air yang digunakan pada saat proses cooling dan permukaan mesin kotor karena kurangnya pengecekan oleh operator. Kemudian kecacatan Sink Marks atau permukaan tidak rata biasanya disebabkan oleh proses penarikan oleh mesin holding/hold off yang terlalu cepat sehingga pipa menjadi tidak sempurna maka perlu dilakukan pengecekan berkala oleh operator sehingga mesin tetap bisa terkontrol.

Dengan demikian, dari penyebab terjadinya kecacatan produk Pipa PVC, maka perlu dilakukan langkah-langkah perbaikan untuk mengurangi produk rusak dan untuk terciptanya produk yang berkualitas. Jika tidak segera dilakukan perbaikan maka akan menimbulkan kerugian oleh perusahaan.

\subsection{Analisis Implementasi FMEA}

Berdasarkan hasil perhitungan metode FMEA diperoleh nilai RPN tertinggi yaitu jenis defect produk bercak/bintik dengan nilai RPN 147, dengan penyebab kecacatan operator lelah. Dan RPN tertinggi yang kedua yaitu jenis defect produk Scratch/gores nilai RPN 126 dengan penybab kecacatan operator kurang melakukan pengecekan. Nilai RPN tertinggi ke 3 yaitu jenis kecacatan bercak/bintik nilai RPN 125 dengan penyebab kecacatan operator asalasalan/tidak sesuai prosedur. Dari 3 nilai RPN tertinggi ini semua dari faktor kecacatan terjadi pada faktor manusia, sehingga perlu dilakukan evaluasi kerja oleh perusahaan terhadap SDM/stakeholder yang ada pada perusahaan demi meminimalisir terjadinya kecacatan yang terjadi.

Pertama untuk mengatasi defect yang di sebabkan operator lelah maka perusahaan harus menambah jumlah operator untuk dapat dilakukan pergantian operator dalam proses produksi sehingga tidak menimbulkan kelelahan. Kedua untuk mengurangi defect yang disebabkan operator kurang melakukan pengecekan, yang perlu dilakukan oleh perusahaan adalah dengan membuat jadwal atau jam kunjungan oleh kepala produksi sehingga proses produksi bisa berjalan lancar dan terpantau dengan baik. Ketiga hal yang perlu dilakukan perusahaan untuk mengurangi defect yang disebabkan oleh oprator asalasalan/tidak sesuai prosedur adalah dengan cara melakukan pelatihan-pelatihan khusus untuk operator sehingga pengetahuan operator bertambah dan juga dilakukan pengawasan oleh kepala produksi atau staf-staf ahli yang terkait proses produksi.

\section{Kesimpulan}

Terdapat 4 points kesimpulan dan dijabarkan sebagai berikut :

1. Teridentifikasi terdapat tiga jenis defect yang ditemukan yaitu defect bercak/bintik, defect sink mark, dan defect scratch/goresan.

2. Hasil perhitungan 7 tools kecacatan ada sebanyak 1.426 pipa defect dari total produksi sebanyak 56.983 selama 4 bulan (September, Oktober, November, Desember) 2018. Jadi dapat disimpulkan bahwa hanya $\pm 2.5 \%$ kecacatan dari jumlah keseluruhan produksi.

3. Hasil analisis perhitungan dari 7 metode pengendali kualitas, kecacatan tertinggi yaitu pada jenis kecacatan bercak/bintik sebanyak 745 atau $52 \%$ dari total kecacatan, dan dapat diketahui bahwa kecacatan tidak melewati batas kontrol atas sehinga dapat dikatakan masih terkendali. Kemudian untuk hasil dari diagram sebab akibat paling dominan yaitu disebakan oleh faktor manusia. Kemudian berdasarkan hasil perhitungan FMEA diperoleh nilai RPN tertinggi adalah jenis kecacatan bercak/bintik dengan penyeban kecacatan operator lelah sehingga proses produksi kurang terkontrol.

4. Untuk menangani hal tersebut maka pihak perusahaan lebih mengontrol kinerja pegawai dan melakukan evaluasi kinerja tersebut agar dapat melakukan perbaikan pada sektor yang memerlukan pembenahan.

Penelitian ini memiliki kelemahan pada data yang digunakan hanya menggunakan data produksi selama 4 bulan, untuk penelitian selanjutnya sebaiknya peneliti menggunakan 
data yang lebih lama sehingga analisis atau perhitungan data yang diperoleh akan lebih akurat dan juga bisa di kombinasikan dengan metode-metode lain seperti sig sixma.

\section{Ucapan Terima Kasih}

Ucapan terimakasih di sampaikan kepada PT. AZ yang telah mengizinkan peneliti untuk melakukan penelitan pada perusahaan serta memfasilitasi penulis selama melakukan penelitan.

\section{Daftar Pustaka}

Andi, T. A., \& Tuwanku, A. A. (2015). Analisis Kecacatan Produk Fillet Skin On Red Mullet Dengan The Basic Seven Tools Of Quality Dan Usulan Perbaikannya Menggunakan Metode Fmea (Failure Modes And Effect Analysis) Pada Pt. Holi Mina Jaya. Jurnal Manajemen Teori dan Terapan, VII, 9-23.

Andrian, Y. B., Muhammad, Y., \& Petrus, W. (2020). Analisis Faktor Penyebab Produk Cacat Pakaian Dengan Metode Statistical Quality Control (Sqc) Dan Failure Mode And Effect Analysis (Fmea) Di Cv. Yussuf \& Co. Jurnal Rekavasi, VIII, 44-51.

Andrianto, E. S., \& Nina, A. M. (2021). Analisis Seven Tools Pada Pengendalian Kualitas Proses Vulkanisir Ban 1000 Ring 20 Di $\mathrm{Cv}$ Citra Buana Mandiri Surabaya. STRING, $V, 252-262$.

Ayu, L., \& Nina, A. (2021). Analisis Defect Proses Produksi Songkok Berbasis Metode FMEA dan FTA di Home Industri Songkok GSA Lamongan. Serambi Engineering, VI, 2197-2206.

Dini, N., \& Evi, Y. (2019). Perbaikan Kualitas Produk Sandal Japit Dengan Menggunakan Metode Failure Mode And Effect Analysis (Fmea) Dan Fault Tree Analysis(Fta). jurnal Institut Teknologi Adhi Tama Surabaya, II, 169176.

Erwindasari, Nurwidiana, \& Brav, D. B. (2019). Penerapan Metode Statistiqal Quality Control (SQC) Dan Failure Mode And Effect Analysis (Fmea) Dalam Perbaikan Kualitas Produk. Klaster Engineering, II, 503-515.
Faisal, W. K., \& Syarif, H. (2017). Analisis Hambatan Dan Rekomendasi Solusi Pada Proses Outbound Logistic Pt Xyz dengan Seven Tools Dan FMEA. Seminar Nasional Inovasi Dan Aplikasi Teknologi, I, C22.1-C22.5.

Farid, S., \& Suhartini. (2019). Analisis Kecacatan Produk dengan Metode Seven Tools dan FTA dengan Mempertimbangkan Nilai Risiko berdasarkan Metode FMEA. Jurnal SENOPATI, I, 41-49.

Habulloh, M. K., \& Dwi, A. S. (2017). Analisis Kegagalan Proses Insulasi Pada Produksi Automotive Wires (Aw) Dengan Metode Failure Mode And Effect Analysis (FMEA) Pada PT. JLC. Sinergi, XX1, 193-203.

Isma, M., \& Hariswan, F. (2018). Analisis Cacat Produk Baju Muslim Di Pd. Yarico Collection Menggunakan Metode Failure Mode And Effect Analysis. JMTSI, II, 43-55.

Suparjo, E. (2019). Analisis pengendalian kualitas produk polyurethane sandwich panel dengan metode old seven tools di PT. ABC. Jurnal Hasil Penelitian, II, 114-119.

Tiara, M., \& Elisabeth, G. (2016). Identifikasi Kecacatan Coil Basah Dan Upaya Perbaikan Dengan Metode Seven Tools Dan Faulure Mode And Effect Analysis (FMEA) Di PT. XYZ Medan. Jurnal Sistem Teknik Industri, XVIII, 101-107.

Tio, P. M., \& Mujiya, U. M. (2018). Aplikasi Seven Tools untuk Mengurangi Cacat Produk White Body pada Mesin Roller. Jurnal Sistem dan Manajemen Industri, II, 59-66.

Vera, D., \& Melany, O. (2021). Usulan Peningkatan Kualitas Pulp Dengan Menggunakan Metode Seven Tools Dan New Seven Tools Di Pt. Ik. Agrointek: Jurnal Teknologi Industri Pertanian, $X V$, 521-536.

Wahyu, D. P., Suyadi, \& Choirul, R. (2017). Pengendalian Kualitas Produksi Rear Caliper Brake System Type 2 Pv Untuk Sepeda Motor Menggunakan Metode Seven Tools. Jurnal Rekayasa Mesin, XII, 23-32. 
Yasarah, H., \& Ida, M. (2021). Ishikawa Diagram dan Failure Mode Effect Analysis (FMEA) sebagai Metode yang sering digunakan dalam Manajemen Risiko Mutu di Industri. Majalah Farmasetika, 